\title{
The Excellence of Cocoa-Goat Integrated Farming in the Implementation of Zero Waste Concept
}

\author{
Ihda Fitriyah ${ }^{1}$, Yuli Hariyati ${ }^{2}$ \\ 1) Student of Study Program of Agribusiness Faculty of Agriculture University of Jember \\ 2) Lecturer of Study Program of Agribusiness Faculty of Agribusiness University of Jember \\ Email: yuli.faperta@unej.ac.id
}

\begin{abstract}
The problem for farmers in Suruh Village is having two types of farming which are cacao-goat integrated system farmer and cacao-goat non-integrated system farmer. The cacao-goat integrated system conducts cacao farming with goat livestock while the cacao-goat non-integrated system does not conduct goat livestock. Farmer's interest is different in conducting a cacao farming system. The aim of the cacao-goat integration system is obtaining manure as organic fertilizer by the expectation to save fertilization cost so that farmer's income with the cacao-goat integrated farming system will be different from non-integrated one because seen from the maintenance cost because of manure. In this study, we dig pattern analysis information of the cacaogoat integrated farming system to find out cacao-goat integrated system and income difference of cacao-goat integrated and non-integrated systems so that it aims to find out the pattern difference of cacao-goat integration farming The research result shows that cacao-goat integrated system by the utilization of cacao waste (bark, leaf), intercropped plant (avocado, cassava, stink beans) as the animal feed of goat). Goat livestock produces feces that can be used as cacao compost fertilizer after 12 months of fermentation. The average income of the cocoa-goat non-integration farmer is USD 1,184.91/Ha/Year, while the cocoa-goat non-integration farmer has an average income of USD 854,673/Ha/Year. There is a significant difference between cacao-goat integrated farming income and cacao-goat non-integrated farming income.
\end{abstract}

Keywords: Cacao, Integration, Income

\section{Introduction}

Cacao (Theobroma cocoa $\mathrm{L}$.) is one of the plantation commodities in which the role is important for national economics, especially as the job field provider, income source, and foreign exchange [1]. In 2002, cacao plantations had provided employment and income sources for around 900 thousand heads of farm families, most of them were located in Eastern Indonesia [2] and contributed the third largest foreign exchange of plantation sub-sector after rubber and oil palm with a value of US \$ 701 million. In terms of quantity, for example, Ivory Coast could reach at least the production of 1.5 tons per hectare, while Indonesia is still around 0.5 tons per hectare [3].

The increase of the cacao planting area has a positive correlation with the increase of cacao production. The increasing number of cacao production is supported by the existence of the government program that is Gernas Kakao (Gerakan Nasional Peningkatan Produksi dan Mutu Kakao). Gernas Kakao is an acceleration effort to increase productivity and quality of national cacao though optimal empowerment to entire stakeholders according to each task and responsibility in cacao agribusiness activity, and available resource. The main activity of the Gernas Kakao program is the rejuvenation of damaged cacao cropping, the rehabilitation of deficient cropping, and the intensification of less productive cropping. The rejuvenation activity is directed to the status of heavily damaged farm marked by old crop. Gernas Kakao program is considered quite effective to 
increase cacao production in Indonesia especially in East Java Province. At present, the demand for cocoa and cocoa-based products in Asia is growing particularly rapidly and chocolate manufacturers are increasing investment in this region [4].

There are 5 regencies in the East which are cacao centers that are Banyuwangi Regency, Jember Regency, Lumajang Regency, Trenggalek Regency, and Kediri Regency. Trenggalek Regency is one of the regencies as the cacao center with a land area of 4,355 ha with a production of 2,590 tons and a productivity of 0.59 tons/ha. The productivity owned by Trenggalek Regency is very few compared to 3 other regencies. The year 2016 was still in the assessment because the cultivation transition of farmers still used non-organic into organic farming. The understanding of socioeconomic and biophysical dynamics of interaction that contributes to variation in the adoption of technologies by smallholder farmers will unravel the key factors that influence their decisions making process [5].

Farmers in Suruh Village have a special feature in cacao farming that is already getting an organic certificate from ICERT given in 2018, using the Rorak and mitigation methods. The member of the farmer group in Suruh Village has two types in cultivation that are cocoa-goat integrated farming system and cocoa-goat non-integrated farming system. Farmer's interest is different in conducting a cacao farming system. The existence of the government program for zero waste concept based on organic from BBPPTP, Surabaya since 2015 triggers to conduct cacao farming with goat livestock. Goat livestock locates at around the cacao plantation. The cacao-goat integrated farming system in Suruh Village utilizes cacao fruit such as rind waste, leaf for goat feed while goat feces for compost on cacao fruit fertilization. Their farming system is by the zero-waste concept.

There are farmers in Suruh Village who are only cacao farmers and do not raise goat. The fertilized used still uses compost fertilizer by buying in a farmer group. The maintenance cost such as fertilizer purchase will be more expensive so that the farmer's income will have an effect. The aim of the cacao-goat integrated system is obtaining manure as organic fertilizer by the expectation to save fertilization cost so that farmer's income with the cacao-goat integrated farming system will be different from non-integrated one because seen from the maintenance cost. Recently, there are many cacao cultivations conducted by the zero-waste system. The aim of this research is to find out : (1) Cacao-goat integrated system (2) Income difference of cacao-goat integrated system and cacao-goat non-integrated system.

\section{Research Methodology}

The research area was determined by using the purposive method or intentionally where the location area is [6]. The research location chosen in this research was Suruh Village Suruh District Trenggalek Regency. This research was based on the decision that Suruh Village, which is one of the cacao production, centers in Suruh District Trenggalek Regency. The land area of cacao commodity in Suruh Village is the highest as much as $98.75 \mathrm{Ha}$. The research method used was descriptive and qualitative. The descriptive method aimed to describe and interpret data in the field that was illustrating the cacao-goat integrated farming system in Suruh Village Suruh District Trenggalek Regency. The analytic method used in this research aimed to test the income difference hypothesis of cacao-goat non-integrated and integrated farming systems in Suruh Village Suruh District Trenggalek Regency [7].

The sample retrieval method in this research was saturation sampling. It is called so because, in this sampling technique, the researcher selected all those units in the sample that contained 'to-bestudied' characteristics [8]. Farmers in Suruh Village who carry out cacao and goat integration systems are 30 farmers while those who do not implement cacao and goat integration systems are 30 
farmers. The total population is relatively small. Data collection in this study used primary data by conducting interviews, observation, and the use of documents.

Data analysis used to finish the fourth problem formulation about income difference of cacaogoat integration and non-integration in Suruh Village Suruh District Trenggalek Regency during one year was using income analysis. The profit calculation can be formulated [9]:

$$
\text { Total Profit }=\text { Total Revenue }- \text { Total Cost (including opportunity cost) }
$$

Notes:

$\pi=$ Net income of integrated $/$ non-integrated cacao farming $(\mathrm{U} \$ \mathrm{D} / \mathrm{Ha})$

$\mathrm{TR}=$ Total Revenue (Total income of integrated/ non-integrated cacao farmers)

$\mathrm{TC}=$ Total Cost (Total cost of integrated/ non-integrated cacao farming)

After the farmer's income of cacao-goat integration and non-integration is known to find out the farmer's income difference or level ratio of integration and non-integration, independent sample ttest analysis is used as follows [10].

$$
\mathrm{t}=\frac{\overline{\mathrm{X}} 1-\overline{\mathrm{X}} 2}{\sqrt{\frac{\left(\mathrm{n}_{1}-1\right) \mathrm{S}_{1}{ }^{2}-\left(\mathrm{n}_{2}-1\right) \mathrm{S}_{2}{ }^{2}}{\mathrm{n}_{1}+\mathrm{n}_{2}+2}\left(\frac{1}{\mathrm{n}_{1}}\right)+\left(\frac{1}{\mathrm{n}_{2}}\right)}}
$$

Notes :

$n_{1} \quad=$ number of samples of integrated cacao farmers

$n_{2} \quad$ number of samples of non-integrated cacao farmers

$\mathrm{X} 1$ = average farmers' income of cacao integration

$\mathrm{X} 2$ = average farmers' income of cacao integration

$S_{1}{ }^{2}=$ deviation standard of integrated cacao farmers

$S_{2}{ }^{2}=$ deviation standard of non-integrated cacao farmers

Decision criteria:

a. $\mathrm{t}$ count $\leq \mathrm{t}$ table, then $\mathrm{H} 0$ is accepted and $\mathrm{H} 1$ is rejected, meaning that there is no difference in the average income level between integrated cacao farmers and non-integrated cacao farmers

b. $\mathrm{t}$ count $>\mathrm{t}$ table, then $\mathrm{H} 1$ is accepted and $\mathrm{H} 0$ is rejected, this means that there is a difference in the average income level between integrated cacao farmers and non-integrated cacao farmers

\section{Result and Discussions}

\subsection{Cocoa-Goat Integrated Farming System}

The integration of cacao with goats in Suruh Village is one of the technologies that aim to optimize the use of land, production cost spent such as compost fertilizer purchase, and income. Cacao plantation with goat livestock has been conducted since 4 years ago in 2015. The program from BBPPTP Surabaya is to develop organic cacao. Livestock was raised by the farmer as a side business to increase income.

The cacao plant produces fruits and leaves. Farmers in Suruh Village commonly sell the cacao seed while the cacao rind is the waste that is processed for animal feed. For cacao rind, it is chopped up first with wood so that goats can digest food easily so that it will not irritate the intestines. Goats need food 1-2 times a day. Besides cacao plants, goat fodder is an intercropped plant such as leaves 
of avocado, leaves of the cassava plant. The place of Etawa crossbred goat pen in Suruh Village is around cacao plant that is planted. Goats need food every day from cacao plant waste and shade plants. Waste or Etawa crossbred goat feces is in the form of urine or solid feces for organic fertilizer of cacao plant so that can increase plant nutrient and can be more environmentally friendly. The way to make compost fertilizer from goat feces is as follows:

1. Goat feces under the pen is cleaned and collected in one place.

2. Then hushed up during 3,6 months until 1 year to be better covered by tarpaulin to keep it moist. When dry season, it is watered using water to keep it wet, the goat feces that has been covered by the tarpaulin.

3. After 3,6 months until 1 year, the goat feces that has been hashed up then chopped up using APPO (Organic Fertilizer Processing Tool) machine.

4. Goat feces that has been chopped up is swept by an iron ring to put it from the APPO machine to the sack.

5. Already used to fertilize cacao plants.

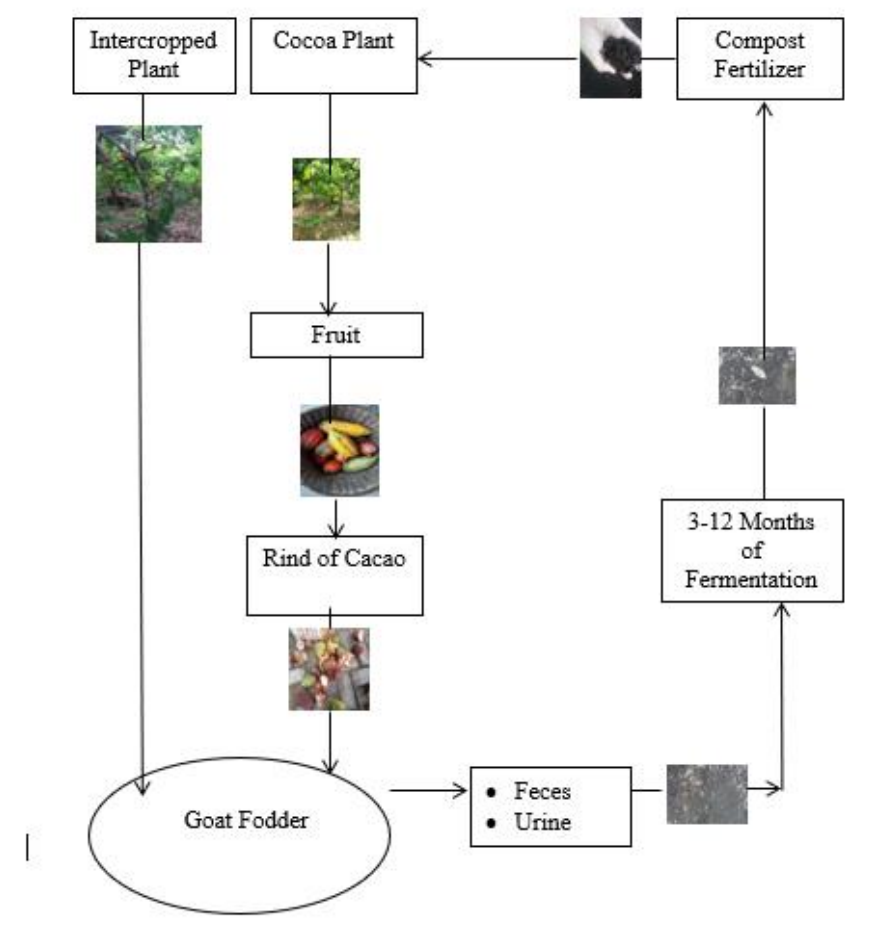

Figure 1. Cacao-Goat Integrated Farming System in Suruh Village

\subsection{Farmers' Income in Cacao-Goat Integrated Farming System with Non-Integrated Farming System}

Income is the final purpose of each farmer to do farming. Income is earned from the revenue minus total cost spent. Total revenue is earned from the multiple of cacao production in the kilogram unit with the selling price while the total cost spent by the farmers consists of fixed cost and variable cost during farming. The existence of income difference earned by cacao-goat integrated and nonintegrated farmers is caused by the total number of cost spent from the revenue earned by cacao-goat integrated and non-integrated farmers The following is the total cost, revenue, and income of cacaogoat integrated and cacao-goat non-integrated farming which can be seen in Table 1. 
Table 1

The Difference of Cost, Revenue, and Income of Cacao-Goat Integrated and Cacao-Goat Non-Integrated Farming

\begin{tabular}{clcc}
\hline No. & Explanation & Cocoa-Goat Integration & Cocoa-Goat Non-Integration \\
\hline 1 & Average Total Revenue (USD/Ha) & $1,754,576$ & $1,357,372$ \\
& a. Revenue of Cacao (USD) & $1,485,126$ & $1,357,372$ \\
& b. Revenue of Goats (USD) & 247,948 & - \\
2 & Average Total Cost (USD/Ha) & 569,635 & 502,699 \\
& a. Labor Cost (USD) & 288,610 & 234,651 \\
& b. Fertilizer Cost (USD) & 163,804 & 174,934 \\
& c. Fixed Cost (USD) & 117,221 & 93,114 \\
3 & Average Income (USD/Ha) & $1,184.941$ & 854,673 \\
\hline
\end{tabular}

Sources: Primary Data Processed (2019)

Based on Table 1 can be explained that the average farmer's income of cacao-goat integration is bigger than the income of cacao-goat non-integration. The farmer's income of cacao-goat integration can be obtained from total revenue of cacao and goat within a year minus total labor cost, fertilizer, and fixed cost spent by the farmers while the farmer's income of cacao-goat non-integration is obtained from total revenue of cacao within a year minus total labor cost, fertilizer, and fixed cost spent $b$ the farmers.

The average income is obtained from the difference between average total revenue and average total cost. The average farmer's income of cacao-goat integration is USD 1,184,941/Ha/Year with the average labor cost breakdown of USD 288,610, fertilizer cost of USD 163,804, and fixed cost of USD 117,221 while the average income of cacao-goat non-integration is USD $854,673 / \mathrm{Ha} / \mathrm{Year}$ with the average labor cost breakdown of USD 234,651, fertilizer cost of USD 174,934, and fixed cost 93,114 . The average labor cost of cacao-goat integrated farmers is bigger than cacao-goat nonintegrated farmers because there is labor to give goat fodder and a goat pen making on the cacaogoat integrated farmers while the average fixed cost is bigger than cacao-goat integration because there is a goat pen making while compost fertilizer cost spent by cacao-goat non-integrated farming is bigger than cacao-goat integrated farming because the farmers do not raise goats so that they buy compost fertilizer for the need of cacao farming (Results of Income Difference Test on the farmer's income of cacao-goat integration and cacao-goat non-integration in Suruh Village are presented in Table 2.

Table 2

Difference Test Analysis Results of Income of Cacao-Goat Integrated and Cacao-Goat NonIntegrated Farming

\begin{tabular}{lccccc}
\hline \multicolumn{1}{c}{$\begin{array}{c}\text { Income } \\
\text { Farmers }\end{array}$} & $\begin{array}{c}\text { Average } \\
\text { Income }\end{array}$ & $\begin{array}{c}\text { Deviation } \\
\text { Standard }\end{array}$ & t-count & Df & $\begin{array}{c}\text { Sig. } \\
\text { (2-tailed) }\end{array}$ \\
\hline Integration & $1,184,941$ & 383.2853 & 3.712 & 58 & .000 \\
Non-Integration & 854,673 & 300.991 & & 58 \\
\hline
\end{tabular}

Sources: Primary Data Processed (2019) 
Based on Table 2 above can be known that the average farmer's income of cacao-goat integration is USD $1,184,941 / \mathrm{Ha} /$ Year with the respondent of 30 farmers, while cacao-goat non-integrated farmers have an average income of USD $854,673 / \mathrm{Ha} /$ Year with 30 respondents.

The testing result is obtained that t-count value of $3.712>$ table of 2.001 with the significance value (Sig. 2-Tailed) that is $0.000 \leq 0.05$ then $\mathrm{H}_{1}$ is accepted $\mathrm{H}_{0}$ is rejected meaning that there is a significant difference between cacao-goat integrated farming with the income of cacao-goat nonintegration. The income of cacao-goat integration and cacao-goat non-integration can be concluded that the farmer's income of cacao-goat integration is bigger than cacao-goat integrated farmers [11]. The significant income difference is because the farmers who do not conduct integration do not have goats to sell per year and only depend on the cacao plantation.

\section{Conclusions}

The main plant in the cocoa-goat integrated system is the cacao plant and the shade plants are stink beans and avocado. Cacao plants produce fruits and leaves, while shade plants are taken of the leaves for goat fodder. Goat manure in the form of urine and solid form were done fermentation for 3-12 months to be made for compost of cacao and shade plants.

The average farmer's income of cocoa-goat non-integration is 1,184,941/Ha/Year, while cocoagoat non-integrated farmers have an average income of $854,673 / \mathrm{Ha} / \mathrm{Year}$. The results of different test analysis are that there is a significant difference between the income of cacao-goat integrated farming and the farmer's income of cacao-goat non-integration.

\section{References}

[1] Anushka, M. Wickramasuriya, and Jim M. Dunwell, (2019). Cacao biotechnology: current status and future prospects. Plant Biotechnology Journal, 16(1), 4-17. US National Library of Medicine National Institute of Health.

[2] Irfany, I., McMahon, P. J., Toribio, J. A., Phan-Thien, K. Y., Rifai, M. A., Yusdiyanto, S., ... \& Nuryartono, N. (2020). Determinants of diversification by cocoa smallholders in Sulawesi. International Journal of Social Economics. 47(10)

[3] Hariyati, Y. (2016). The Management Product in the Farmers Level and the Role of Supporting Institutions for Cocoa Fermentation Process. Agriculture and Agricultural Science Procedia, 9, 128133.

[4] Wickramasuriya, A. M., \& Dunwell, J. M. (2018). Cacao biotechnology: current status and future prospects. Plant biotechnology journal, 16(1), 4-17.

[5] Asare, R, B., Danquah, J, A., and Frempong, F, A. (2013). Socioeconomic Factors Influencing Adoption of Codapec and Cocoa High-Tech Technologies among small Holder Farmers in the Central Region of Ghana. American Journal of Experimental Agriculture, 3(2): 277-292.

[6] Cempaka, L., Aliwarga, L., Purwo, S., and Kresnowati, M, T, A, P. (2014). Dynamics of Cocoa Bean Pulp Degradation during Cocoa Bean Fermentation: Effects of Yeast Strater Culture Addition. Journal of Mathematical and Fundamental Sciences, 46 (1).

[7] Gunawan and I.G.S. Budisatria, (2016). Technology Innovation in Cocoa-Goats Integration System for Increasing Productivity and Farmers Income in Kulon Progo Regency, Yogyakarta Special Region Province, Indonesia. Asian Journal of Animal Sciences, 10(6): 273-279.

[8] Asthana. H. R. and B. Bhushan. (2007). Statistics for Social Sciences. Delhi: Asoke K. Ghosh.

[9] Baumol, W. J, and A. S. Blinder. 2016. Economics: Principles and Policy. Boston: Cengage Learning.

[10] Taher, S. (1996). Factors influencing smallholder cocoa production: a management analysis of behavioral decision-making processes of technology adoption and application.

[11] Rusdiana, S., \& Hutasoit, R. (2019). Feasibility Study of Financial Economics on Combination Goat Farming and Cacao Farm By Farmers. The International Journal of Tropical Veterinary and Biomedical Research, 4(1), 23-31. 